Article

\title{
Port Cities within Port Regions: Shaping Complex Urban Environments in Gdańsk Bay, Poland
}

\author{
Karolina A. Krośnicka, Piotr Lorens * and Eliza Michałowska \\ Department of Urban Design and Regional Planning, Faculty of Architecture, Gdańsk University of Technology, Poland; \\ E-Mails: karolina.krosnicka@pg.edu.pl (K.A.K.), piotr.lorens@pg.edu.pl (P.L.), elizaa.michalowska@gmail.com (E.M.)
}

* Corresponding author

Submitted: 13 February 2021 | Accepted: 16 April 2021 | Published: 27 July 2021

\begin{abstract}
Port cities located within various metropolitan or functional regions face very different development scenarios. This applies not only to entire municipalities but also to particular areas that play important roles in urban development-including ports as well as their specialized parts. This refers also to the various types of maritime industries, including the processing of goods, logistics operations, shipbuilding, or ship repairing, to name just a few. Since each of these activities is associated with a different location, any transformation process that creates changes in geographic borders or flows will dynamically affect the port cityscape. Municipalities may evolve in different directions, becoming 'major maritime hubs,' 'secondary service centers,' 'specialized waterfront cities,' or just distressed urban areas. Within each metropolitan area, one can find several cities evolving in one of the above-mentioned directions, which results in the creation of a specific regional mosaic of various types of port cities. These create specific 'port regions' with specific roles assigned to each of these and shape the new (regional) dimension of the geography of borders and flows. As a result, these port regions are created as porous structures where space is discontinuous. To further develop the issue of the creation and evolution of port regions, the authors present the case study of the Gdańsk Bay port region. This study in particular allowed for the development of both the theoretical background of this phenomenon and the presentation of a real-life example.
\end{abstract}

\section{Keywords}

Gdańsk; Gdynia; Kaliningrad; Poland; port city; port regions

Issue

This article is part of the issue "Planning for Porosity: Exploring Port City Development through the Lens of Boundaries and Flows" edited by Carola Hein (Delft University of Technology, The Netherlands).

(C) 2021 by the authors; licensee Cogitatio (Lisbon, Portugal). This article is licensed under a Creative Commons Attribution 4.0 International License (CC BY).

\section{Introduction}

Exploration of port city development calls not only for an analysis of the evolution of internal and external boundaries and flows of goods and passengers but also for studies on the consequences of regional transformation processes. This translates into planning decisions, which can also deal with the entire conglomerates of port cities. Therefore, one should note that ports and port cities exist not only as 'stand-alone entities,' but also as nodes within their 'catchment areas' or centers within their 'functional regions.' These port-city areas are shaped by factors similar to ones influencing the development of metropolitan areas (e.g., Faludi, 2009). Due to the duality of their function, to fulfill city functions and also provide for diverse port activities that shape development processes of these entities, these 'port functional areas' may be identified as 'port regions,' which accumulate port cities of a different role, size, and location.

The effects of port activities on the regional economy are quite widely studied in the literature (Ferrari et al., 2012; Munim \& Schramm, 2018; Park \& Seo, 2016). Some authors noticed, however, that within the last decades, due to changes occurring in the shipping market, including the process of containerization, the effect of port activity on the region decreased, and often the 
economic benefits moved from the port region to more distant regions (Brooks \& Cullinane, 2007; Krośnicka, 2018; Musso et al., 2000). The social costs however are still mostly paid by inhabitants of the port region (Hoyle \& Hilling, 1984). This process, known as 'demaritimization' (Ferrari et al., 2012), having measurable spatial consequences, is paradoxically being enabled by the infrastructural and technological improvements in port accessibility (via new roads, railways, new transport, and logistic systems). On the other hand, historically in port regions, it was often the lack of new infrastructural investments that led to the loss of the port's significance within the regional structure and even to its fall. The geographies of these port regions are thus shaped by several exogenous and endogenous factors that contribute to dynamic changes in their boundaries (Lorens, 2014). The scope of factors shaping port regions may include several elements such as:

- Technological: Changes in maritime transport and cargo-handling technologies, which may favor some port cities over others;

- Infrastructural: Development of a certain infrastructure type, which may be located only in some port cities that constitute a certain functional area;

- Economic: Differences in economic realities, which may contribute to unequal development in particular parts of the theoretically conceptualized port region;

- Political: Establishment of new political entities or politically-driven decision-making regarding the location of some infrastructure type, which may result in changing the development course of the port region;

- Social: Change in trends and emergence of new tendencies, which may result in the abandonment of certain development concepts in some parts of port regions;

- Environmental: Conditions and existing resources, which may be deemed unsuitable for the location of new port infrastructure sites.

These factors may be explored to a much larger extent than within this short description and can be discussed according to their endogenous or exogenous nature. Factors contributing to the process of redirecting flows of people and cargo that influence the structure of port regions refer to issues described in the fields of economics and human geography (Ducruet, 2009; Ducruet et al., 2015; Notteboom et al., 2009; Notteboom \& Rodrigue, 2005; Stavroulakis \& Papadimitriou, 2016; Wiegmans \& Louw, 2010), social sciences (Hein, 2014; Hein \& van Mil, 2019; Schubert, 2018), politics (Daamen \& Vries, 2013; Ng et al., 2014; Ressano Garcia, 2008), and technical and technological sciences (Bird, 1963; Ferrari et al., 2012; Hoyle, 1993; Munim \& Schramm, 2018).

The authors selected the Gdańsk Bay port region as the case study. This region is formed by several port cities, located within the present-day borders of northern Poland and the Kaliningrad Region of the Russian Federation (see Figure 3). Due to the complex interrelations between these particular port cities and the rich history associated with their evolution, this case may be regarded as a representative example of a port region phenomenon and serve as the basis for further research regarding its nature. At the same time, the study aims to outline the evolution of changes in the functional structure of the Gdańsk Bay port region and to indicate the impact of selected technological and infrastructural, economic, and political factors on the shaping of port cities and port regions. Neither the social nor environmental aspects of this phenomenon were discussed, as the authors believe these played a less important role in the process of shaping the Gdańsk Bay port region.

Firstly, it seems especially important to discuss the historical relation a port has had to its regional hinterland. This relation has changed throughout the ages, having been influenced by the development of new transport technology and the evolution of ports themselves. Consequently, the borders of the areas served and the regional relations between particular ports were changing as well. This also related to the definition and nature of the port itself, which was once defined as a place of changing the means of transport from inland to waterbased. One should note, however, that although nowadays the economic significance of many historic ports has been diminished, they are still considered important centers for economic and cultural exchange. Nevertheless, the development and transformation of these portswhether in history or nowadays-depends on their geographic location and is strongly related to both the inland background (region) and other port centers (Hoyle \& Pinder, 1981).

The regionalization process in port cities has been widely examined in terms of transport connections and cargo flow through their hinterland (Notteboom et al., 2009; Notteboom \& Rodrigue, 2005). The authors, however, examine the surrounding area of a port city (with a diameter of about $200 \mathrm{~km}$ ) in terms of its dynamically changing functional borders due to technological, economic, and political reasons, as well as processes of transformation (caused by these emerging conditions) affecting the network of nearby towns and cities such as changing the hierarchy of their interconnections and their role in the settlement system. The aim of the article is therefore to visualize the importance of the influence of global decisions of various characters on port regions and their local context, and at the same time to present the evolution of porosity in the Gdańsk Bay port region.

\section{Theoretical Framework}

The emergence and evolution of the port region may result in the creation of a diverse network of centers of different spatial and functional importance (Sassen, 
2010), which are interconnected by diverse types of infrastructures (Haynes, 2010) and social as well as business connections. In this process, due to complex causes, some centers gain importance in the structure of the given region, while others lose it. Bird (1963) first described this process of emergence and how the port region takes shape by distinguishing the phases of setting, expansion, and specialization. Later on, Notteboom and Rodrigue (2005) further developed this concept by adding the phase of regionalization in connection with intensification of transport and logistics between the port's hinterland and foreland. On this basis, Notteboom and Rodrigue (2005) proposed a model of the spatial development of a port system. The model indicated certain phases of interrelation appear among ports located in a port region as scattered ports, penetration and hinterland capture, interconnections and concentration, centralization, decentralization, and regionalization.

This history of the development of port cities cannot be separated from the evolution of sea transport technologies. This evolution was of great influence over the shape, development, and, finally, degradation of various port structures (Hall, 1993). Such changes in the interrelation between the port and cities can be described in different ways. One model study of this issue that is widely discussed and quoted in literature was prepared by Hoyle (1998).

Based on the above-mentioned models, it was possible to analyze the major similarities and differences in the evolution of port regions in the case study of the Gdańsk Bay port region (Table 1).

The set of evolutionary stages presented above could be further expanded to include potential-probable in the near future-changes in port-city development patterns resulting from the policy of 'greening' maritime trade and port-related operations (see European Sea Ports Organisation, 2020). However, since the scope and nature of these changes are not yet clear, the authors decided not to include speculations on the future transformations within this article.

Among the changes defined in Table 1, the increase in maritime transport significance during the industrial revolution seems to be the most important. This is because water transport has proved the most convenient and the cheapest of means for the transport of goods, as the railway system was insufficiently developed at that stage. However, the port structures developed in the late 19th century could no longer meet the requirements of developing demand and the subsequent evolution of maritime transportation technologies. This is especially related to the development of such technologies as container transport, ro-ro cargo handling, and new technologies for dealing with bulk cargo (Hoyle, 1996).

The development of contemporary ports (Phases 5 and 6 of Notteboom and Rodrigue's, 2005, classification, often referred to as third-generation ports) also resulted in the development of a new phenomenon trespassing the boundaries of a single city: the appearance of 'port regions.' In the time of the earlier generations of ports, a given city/town with its direct background constituted its own 'port region'. Only in a few cases were catchment areas-including civic and industrial centers located within them-related to a given seaport, which resulted in the development of the 'port region.' However, the appearance of contemporary specialized terminals located within ports has radically changed the situation. This means that contrary to the previous generations, in which terminals were prevalently built within the existing port cities, the contemporary specialized terminals have appeared in the structure of only a few of the old ports and, at the same time, these have been created in areas previously unused for cargo shipment purposes. Thus, multiple cities can be found within a single 'port region,' including ports of the earlier generations, although there is usually only a single thirdgeneration port while different cities may be hosts to separate terminals of various specialization. The appearance of third-generation ports along with the emergence of 'port regions' contributed to the abandonment or diminishing of the role of many old port structures, now not compatible with new technologies of reloading and transport. As a result, the above-mentioned port-city structures may evolve in different directions to become: 1) 'major maritime hubs' providing the location of third-generation port structures as well as of other types of transportation and industrial infrastructure; 2 ) 'secondary service centers' (or cities) that are still developing but have no prospects for the development of modern cargo-handling infrastructure; or 3) 'specialized waterfront cities' providing places where non-cargo handling maritime economy sectors may develop, including water-based recreation, specialized fishing industries, or other maritime-related services.

The authors decided to present this evolution using the example of the City of Rotterdam (Figure 1). Developed by Meyer (1999), the city was facing numerous phases of development, which led to the creation of a diversified regional structure. Of course, there are also many other cases illustrating the port city and port region development phenomena-including those of urban and/or regional scales. It is anticipated that other authors may use such cases for further research and to build more complex typologies of possible interrelations.

According to Meyer (1991), stages of development of the port city of Rotterdam include:

- Original settlement: Development of the port within an enclosed city (the Middle Ages until the mid-19th century);

- Port growth in the industrial era: Port structures develop along the river, and the division of the port and city has begun (mid-19th century until the early 20th century);

- Development of the industrial port along with a functional city: Both port and city become autonomous structures (mid-20th century); 
Table 1. Comparison of evolutionary stages of the port-city interrelation.

\section{Period \\ Stage of development of the \\ Consequences for the}

port cities a

(1998) and Meyer (1991)

Until the

19th century

I. Simple urban and port structures-the creation of the so-called first generation of ports.

\section{9th-early} 20th century

\section{Developing the port} city-the creation of the so-called second generation of ports. creation of port regions



\section{Close spatial and functional inter-relation of the port and city. No close}

cooperation between port cities and ports despite some exceptional

Europe-wide political and commercial structures,

e.g., Hansa.

The rapid development of industrial and commercial functions separates the port from the city spatially, which permits the development of modern wharves, along with industrial and storage areas. Modern port structures are developed only at selected locations, not in the case of each existing port city.

\begin{tabular}{|c|c|c|c|}
\hline $\begin{array}{l}\text { Spatial development } \\
\text { of a port system } \\
\text { according to } \\
\text { Notteboom and } \\
\text { Rodrigue (2005) }\end{array}$ & Period & $\begin{array}{l}\text { Stage of } \\
\text { development of } \\
\text { Gdańsk Bay } \\
\text { harbor region }\end{array}$ & $\begin{array}{l}\text { Consequences for the creation of } \\
\text { Gdańsk Bay port region }\end{array}$ \\
\hline $\begin{array}{l}\text { Phase 1: Scattered } \\
\text { ports. } \\
\text { Phase 2: Penetration } \\
\text { and hinterland } \\
\text { capture. }\end{array}$ & $\begin{array}{l}\text { Until the } \\
\text { 19th century }\end{array}$ & $\begin{array}{l}\text { Water transport } \\
\text { domination. }\end{array}$ & $\begin{array}{l}\text { The privileged position had ports } \\
\text { located at the river mouth. The } \\
\text { hierarchy was however dependent on } \\
\text { the surface of the river basin-the } \\
\text { larger the river basin, the bigger the } \\
\text { cargo flow passing through the port } \\
\text { city (the case of Gdańsk). Thus, } \\
\text { watersheds formed the borders of } \\
\text { ports' hinterlands, even more than the } \\
\text { country's borders. }\end{array}$ \\
\hline
\end{tabular}

Phase 3:

Interconnections

19th-early and concentration of a port system.
Railway transport domination. 's borders.

With the introduction of the railway system (in the Gdańsk Bay port region as early as 1860), the port's hinterland expanded towards the biggest cities (Toruń, Poznań, Wrocław, Szczecin, Berlin), almost independent of environmental conditions. The privileged ports were those having multidirectional railway access or forming railway hubs. The country's railway transport policy shaped the hierarchy of cities and ports. In the case of ports, the issue was also the depths of waterways. 
COGITATIO

Table 1. (Cont.) Comparison of evolutionary stages of the port-city interrelation.

\begin{tabular}{|c|c|c|c|c|c|c|}
\hline Period & $\begin{array}{l}\text { Stage of development of the } \\
\text { port cities according to Hoyle } \\
\text { (1998) and Meyer (1991) }\end{array}$ & $\begin{array}{l}\text { Consequences for the } \\
\text { creation of port regions }\end{array}$ & $\begin{array}{l}\text { Spatial development } \\
\text { of a port system } \\
\text { according to } \\
\text { Notteboom and } \\
\text { Rodrigue (2005) }\end{array}$ & Period & $\begin{array}{l}\text { Stage of } \\
\text { development of } \\
\text { Gdańsk Bay } \\
\text { harbor region }\end{array}$ & $\begin{array}{l}\text { Consequences for the creation of } \\
\text { Gdańsk Bay port region }\end{array}$ \\
\hline $\begin{array}{l}\text { Mid-20th } \\
\text { century }\end{array}$ & III. Modern port city. & $\begin{array}{l}\text { Industrial and commercial } \\
\text { development, (including the } \\
\text { oil industry) along with the } \\
\text { introduction of container } \\
\text { and ro-ro technologies } \\
\text { entirely separates the port } \\
\text { from the urban area. } \\
\text { Differences between } \\
\text { modernized and stagnating } \\
\text { port cities are contributing } \\
\text { towards changes in regional } \\
\text { economic and } \\
\text { infrastructural structures. }\end{array}$ & $\begin{array}{l}\text { Phase 4: } \\
\text { Centralization of a } \\
\text { port system. }\end{array}$ & $\begin{array}{l}\text { Interwar } \\
\text { period } \\
(1918-1945)\end{array}$ & $\begin{array}{l}\text { Political decisions } \\
\text { of the Treaty of } \\
\text { Versailles (1919). }\end{array}$ & $\begin{array}{l}\text { The Gdańsk Bay port region is an } \\
\text { unusual case due to the political } \\
\text { decision to create the Free City of } \\
\text { Gdańsk. This act separated the port } \\
\text { from its natural hinterland and caused } \\
\text { the building of a competitive seaport } \\
\text { in Gdynia and the fishing port of } \\
\text { Władysławowo within the borders of } \\
\text { this greater region. Although cargo } \\
\text { transport was concentrated mostly in } \\
\text { the port of Gdańsk, the emergence of } \\
\text { the port of Gdynia impacted the } \\
\text { centralization process of the port } \\
\text { system so that this case is not fully in } \\
\text { line with the theoretical model. }\end{array}$ \\
\hline 1960-1980 & $\begin{array}{l}\text { IV. The abandonment of } \\
\text { historic waterfronts-due to } \\
\text { the creation of the so-called } \\
\text { third generation of ports } \\
\text { V. Revitalization of } \\
\text { waterfronts (although these } \\
\text { two periods in Hoyle's, 1998, } \\
\text { original classification were } \\
\text { treated as separate; in the } \\
\text { subsequent works by Meyer, } \\
\text { 1999, they were treated as } \\
\text { one. This also corresponds to } \\
\text { the situation of }\end{array}$ & $\begin{array}{l}\text { Technological changes in } \\
\text { maritime transport compel } \\
\text { the development of } \\
\text { post-industrial structures } \\
\text { independent of the city. } \\
\text { Developed at the same } \\
\text { time, large-sized maritime } \\
\text { terminals have consumed } \\
\text { vast areas of land; parallel } \\
\text { to this is the completed } \\
\text { re-development of the } \\
\text { waterfront for } \\
\text { urban purposes. }\end{array}$ & $\begin{array}{l}\text { Phase 5: } \\
\text { Decentralization of a } \\
\text { port system (spatial } \\
\text { distribution of } \\
\text { transport and } \\
\text { logistic objects } \\
\text { within the port } \\
\text { region). }\end{array}$ & $\begin{array}{l}\text { Socialistic } \\
\text { port-city } \\
(1945-1989)\end{array}$ & $\begin{array}{l}\text { Iron curtain } \\
\text { period. }\end{array}$ & $\begin{array}{l}\text { The reorganization of the political } \\
\text { structure of Europe and the } \\
\text { introduction of the iron curtain } \\
\text { changed the country's borders and the } \\
\text { range of the Gdańsk Bay port region } \\
\text { hinterland. The strong emphasis on } \\
\text { industrialization by countries within } \\
\text { the socialistic block caused the } \\
\text { development of coal, ore, and oil } \\
\text { ports in Gdańsk (north port). Still } \\
\text { based on railway transportation, the } \\
\text { port region was concentrated on bulk } \\
\text { cargo and the shipyard industry. }\end{array}$ \\
\hline
\end{tabular}

post-socialist cities). 
Table 1. (Cont.) Comparison of evolutionary stages of the port-city interrelation.

\section{Period \\ Stage of development of the \\ Consequences for the}

port cities according to Hoyle

(1998) and Meyer (1991)

1980-Today VI. Reconstruction of city-port interrelation. creation of port regions

(1)

\begin{tabular}{llll}
$\begin{array}{l}\text { Consequences for the } \\
\text { creation of port regions }\end{array}$ & $\begin{array}{l}\text { Spatial development } \\
\text { of a port system } \\
\text { according to } \\
\text { Notteboom and } \\
\text { Rodrigue (2005) }\end{array}$ & Period & $\begin{array}{l}\text { Stage of } \\
\text { development of } \\
\text { Gdańsk Bay } \\
\text { harbor region }\end{array}$ \\
\hline $\begin{array}{l}\text { Globalization requires } \\
\text { changes in the modal } \\
\text { functioning of the port and } \\
\text { the re-establishment of its } \\
\text { links with the city. }\end{array}$ & $\begin{array}{l}\text { Phase 6: } \\
\text { Regionalization } \\
\text { (investments of a } \\
\text { port system located } \\
\text { in the further } \\
\text { hinterland and } \\
\text { foreland). }\end{array}$ & $\begin{array}{l}\text { After } \\
\text { 1990-A } \\
\text { post-socialist } \\
\text { port city }\end{array}$ & $\begin{array}{l}\text { Car transport } \\
\text { domination, } \\
\text { containerization, } \\
\text { and entering the } \\
\text { EU. }\end{array}$ \\
& & &
\end{tabular}

The three factors (development of car transport, global containerization processes, and entering the EU) caused the development of the transport and logistic sectors and their facilities within the main ports of Gdańsk and Gdynia (the emergence of new deep-water ports and logistic zones along main access roads) and reshaped the structure of the region.

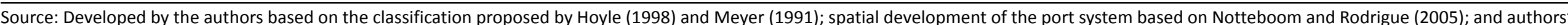
analysis of Gdańsk Bay port region. 


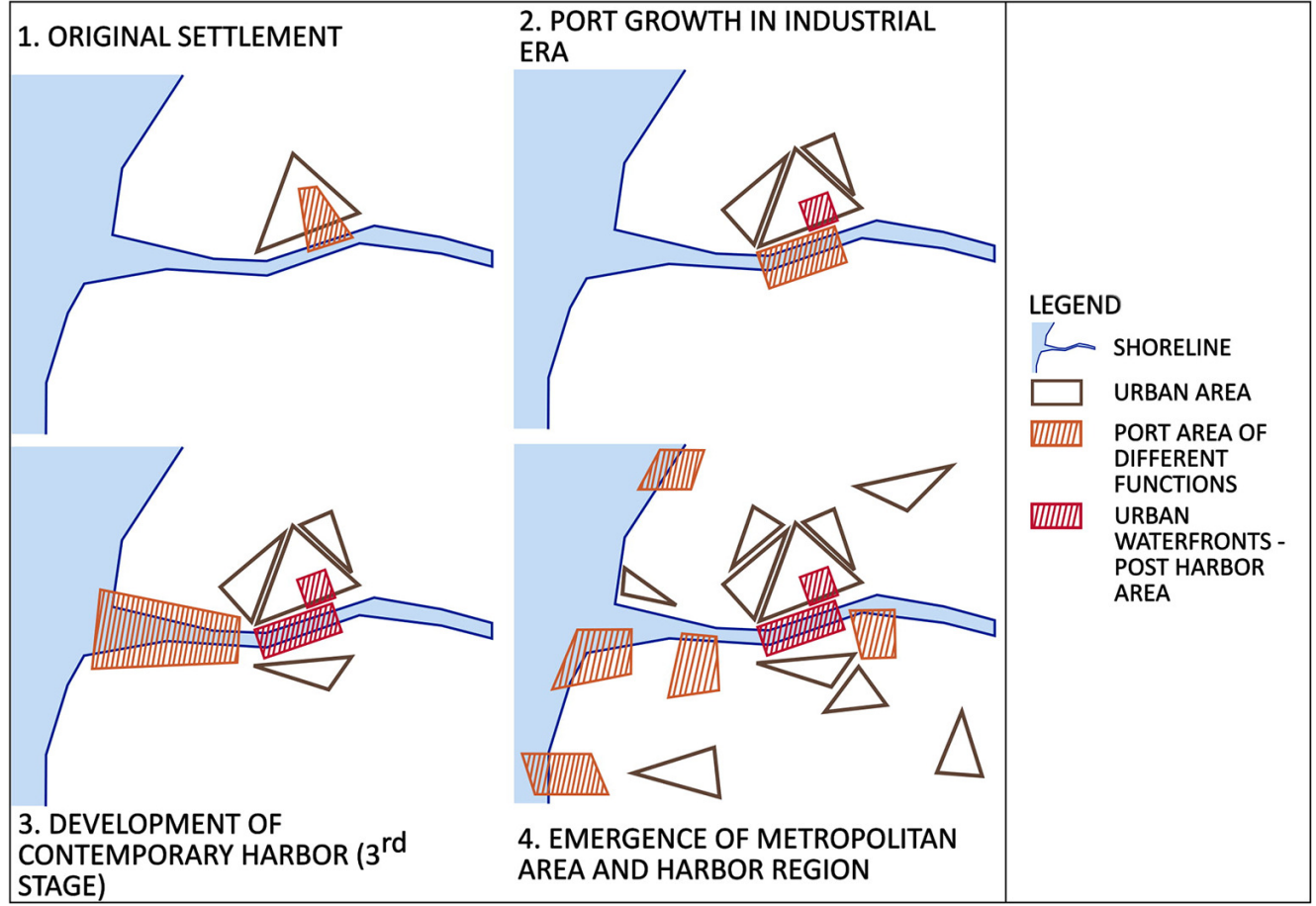

Figure 1. Rotterdam: The evolution of the port-city area. Source: Based on Meyer (1991), reinterpreted by the authors.

- Creation of specialized terminals and port structures along with the network of cities and creation of the port region (since the end of the 20th century).

This example shows the evolution of a port city into a port region, which also created opportunities for the diversification of roles and functions of particular cities within its porous structure. On that basis, it is possible to speculate on the evolving roles of its particular parts (Figure 2).

As indicated in Figure 2, the structure of the contemporary port-city structure may become more complicated than just the development of the network of port terminals and service centers. Within it, one can identify three groups of entities, and each of them may be composed of at least three types of structures (i.e., urban port and waterfront structures). These may include:

- City areas:

- Historic urban centers;

- Declining districts, including working-class areas;

- Developing middle-class suburbs.

- Port areas:

- Contemporary deep-water port terminals;

- Declining historic port areas;

- Specialized non-industrial port areas.

- Waterfront areas:

- Regenerated urban waterfronts;

- Developing waterfront sites;
- Possible future sites of urban waterfront development.

It should be underlined that the roles of these cities and their parts may rapidly change due to currently unforeseen political, economic, or environmental changes. Also, one should note that the current spatial re-arrangement of port cities results-among others-from processes of decreasing significance of mass production as well as from the fact that new types of industrial production areas are rarely linked to the historic locations of industrial activities (Jałowiecki, 1999). As a result, a phenomenon of progressing competition between cities and regions may be observed. Also, there is still some competition inside such a module, which poses a deadly threat to the unity of the whole structure and its position on the world market (van den Berg et al., 1997).

\section{Evolution of the Port Region Geography in the Gdańsk Bay Area}

Gdańsk Bay is located on the southern coast of the Baltic Sea (Figure 3). Most of its waters are within the Polish economic zone, although the eastern shore belongs nowadays to the Russian Federation. Historically, the group of main port cities constituting the contemporary Gdańsk Bay port region included Gdańsk, Elbląg, and Kaliningrad. Also, several small-scale port cities-located both within the analyzed area (Braniewo, Frombork, and Puck) as well as within its catchment area (Łeba and Ustka)-were identified within its boundaries. A network of these cities was established in the Middle Ages under the rule of Order of the Teutonic Knights. This 


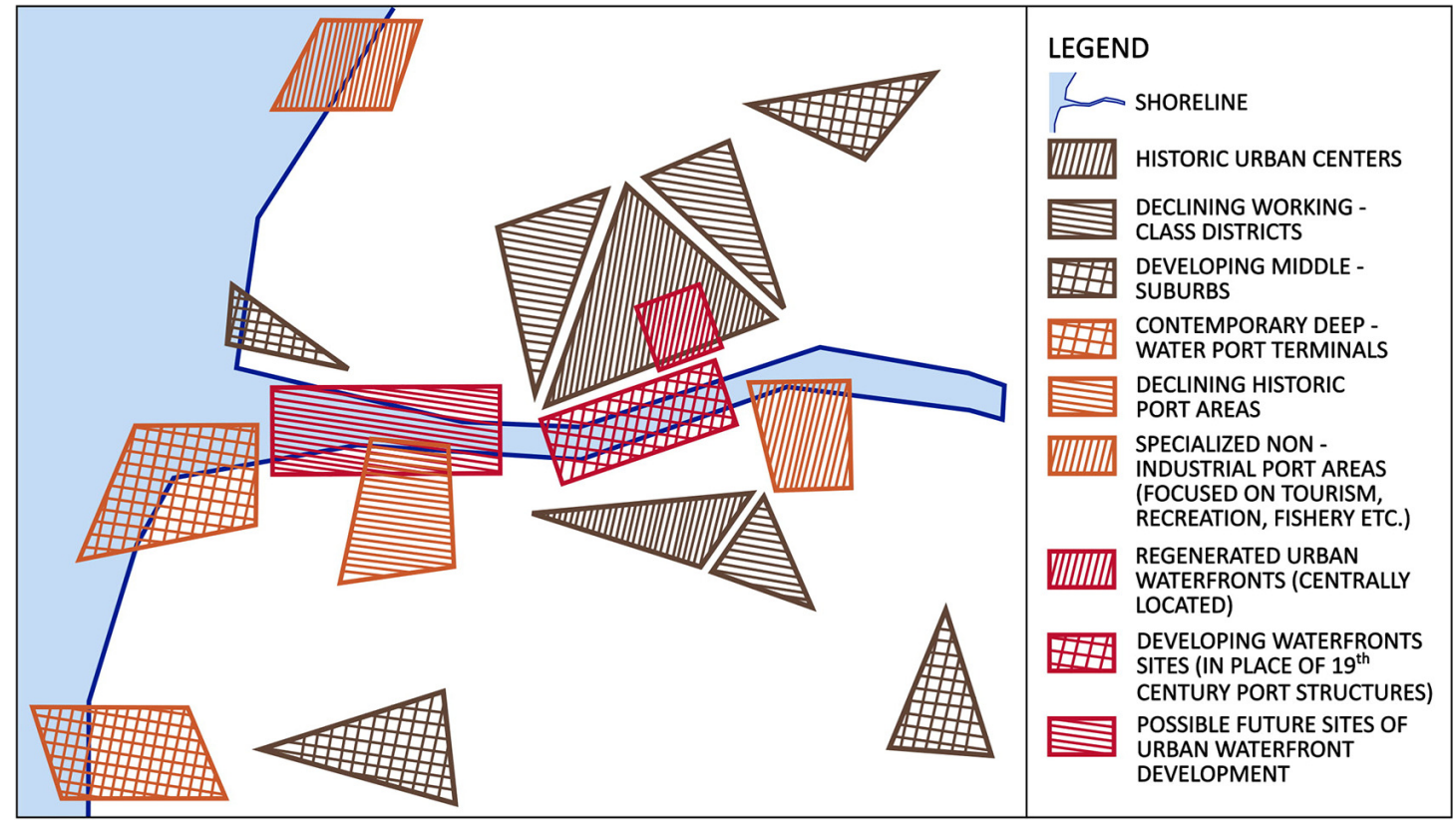

Figure 2. Rotterdam: The hypothetical diversification of port-city area within the porous port region. Source: Based on the interpretation of a drawing by Meyer (1999).

network was complemented by port cities-including Gdynia and Władysławowo that developed within the interwar period.

The port region of the Gdańsk Bay has changed its shape many times in its history, and the cities and ports in its area have assumed different positions in the hierarchy of the settlement structure. This phenomenon was caused by the frequently changing state and adminis- trative borders, but also by the changing range of the economic hinterland of ports (understood as the area of gravity for cargo to the port). In the first case, the changes were driven by political decisions. The changes in the shape of the economic hinterland were, in turn, caused primarily by the technological evolution of transport infrastructure and the transition from the use of inland water transport to rail and then road transport.

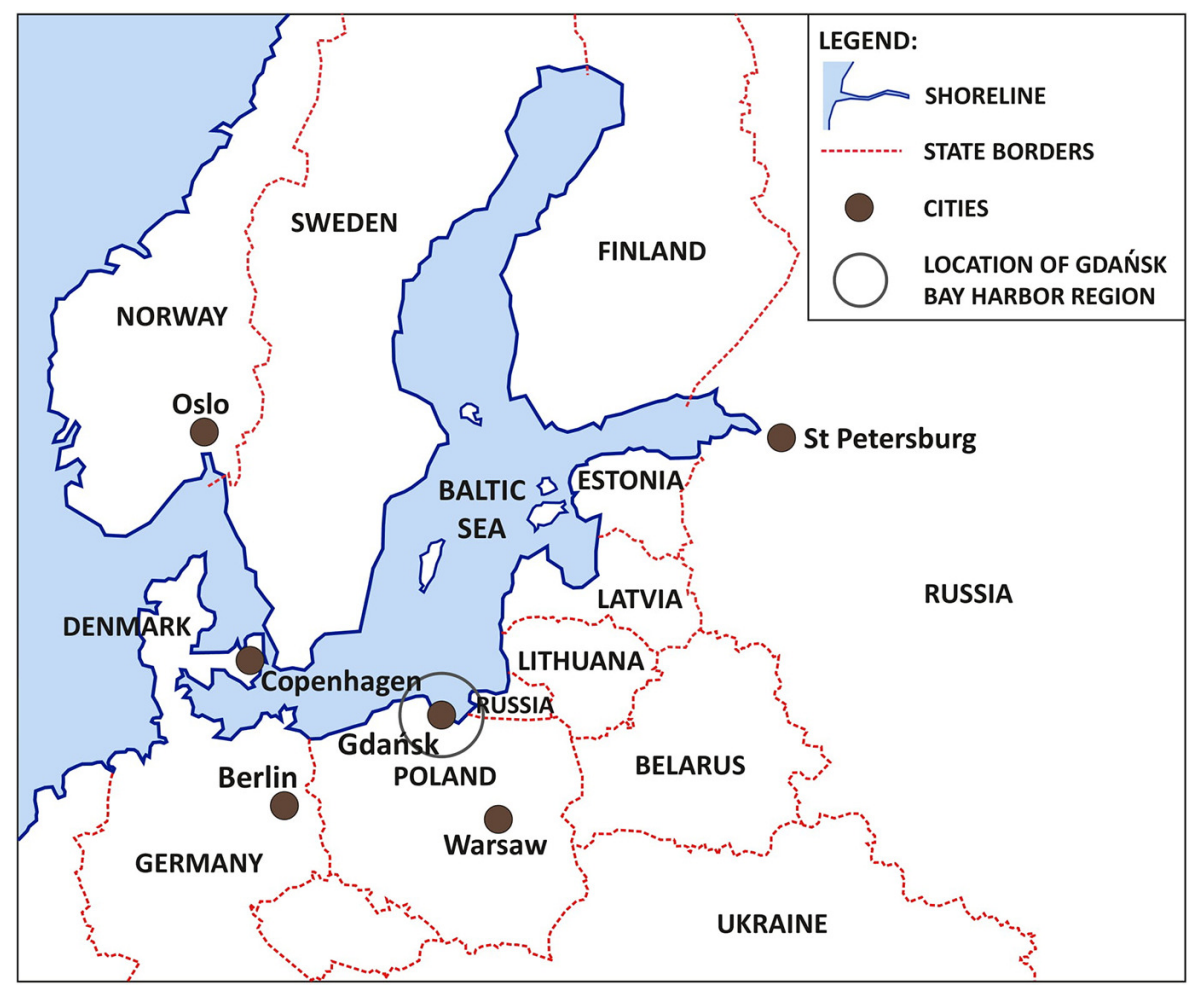

Figure 3. Location of the Gdańsk Bay port region. 
In the history of the Gdańsk Bay port region, five successive phases have been described, referring to the stages of the port-city interrelation and its evolution (Table 1 ) as well as the transformations of its borders and cargo flows within it:

- From the mid-11th to the mid-19th century, when the functional and spatial structure of the Gdańsk Bay port region was based on the natural hydrological system. At the time when rivers were the main means of transporting people and goods, the period of crystallization of the settlement structure in the Teutonic State and the functioning of the Hanseatic League stood out (Figure 4);

- At the turn of the 19th and 20th centuries, when the geography of the Gdańsk Bay port region was based on the railroad system (Figure 5);

- During the interwar period (1919-1939), when the Free City of Gdańsk was established under the Versailles Treaty of 1919, as a result of which a competitive port in Gdynia and a modern fishing port in Władysławowo were built in the vicinity of Gdańsk (Figure 6);

- As the People's Republic of Poland (1945-1989), when the port region of the Gdańsk Bay was based on the development of the shipbuilding industry and handling of bulk cargo (coal, ore, and oil). The administrative reform of the country also had a significant impact on the structure of the region, introducing a two-tier administrative division into a province and a commune (Figure 7);

- Currently, since the post-socialistic period of 1990, in which the structure of the Gdańsk Bay port region is primarily defined by Poland's entry to the $\mathrm{EU}$ and the road system and the global container system based on it (Figure 8).
These stages also reflect the evolution of porosity in the Gdańsk Bay port region. Political and technological changes, contributing to the shape and range of port region borders, result in the porous character of the geography of both port cities and their hinterland.

\subsection{Water Transport Domination}

The Hanseatic League was a community of traders whose interests were based on maritime trade and using political and military means to secure trade privileges (Dollinger, 1975). Gdańsk was an important stop on the main Hanseatic trade route, which connected the following cities: Novgorod-Tallinn-Riga-Visby-GdańskStralsund-Lübeck, Hamburg-Bruges, and London (North, 2018). From 1308 to 1454, the port region of Gdańsk was entirely in the hands of the Teutonic Order, bordering the Holy Roman Empire of the German Nation in the west, Poland in the south, and Lithuania and Livonia in the east. In the area of Teutonic Prussia, the most important centers were the port cities of Gdańsk, Elblag, Königsberg (now Kaliningrad), and Toruń, located on the border with Poland (North, 2018).

Gdańsk was located at the mouth of the Vistula River, which at that time was the main transport corridor in this area of Europe and had extensive economic facilities covering Poland and Hungary (the area of today's Slovakia), with trade contacts reaching through Lviv to the Black Sea (North, 2018). Hanseatic ships (cogs), having a relatively low draft, sailed with luxury goods, amber, and linen to Torun and further to Kraków. On their way, these ships collected cargo from port cities on the Vistula River, usually located at the mouths of smaller rivers to the Vistula (Świecie, Grudziądz, Kwidzyn, and Gniew). Since these rivers were the main communication routes in the region (Figure 4), the Vistula ports

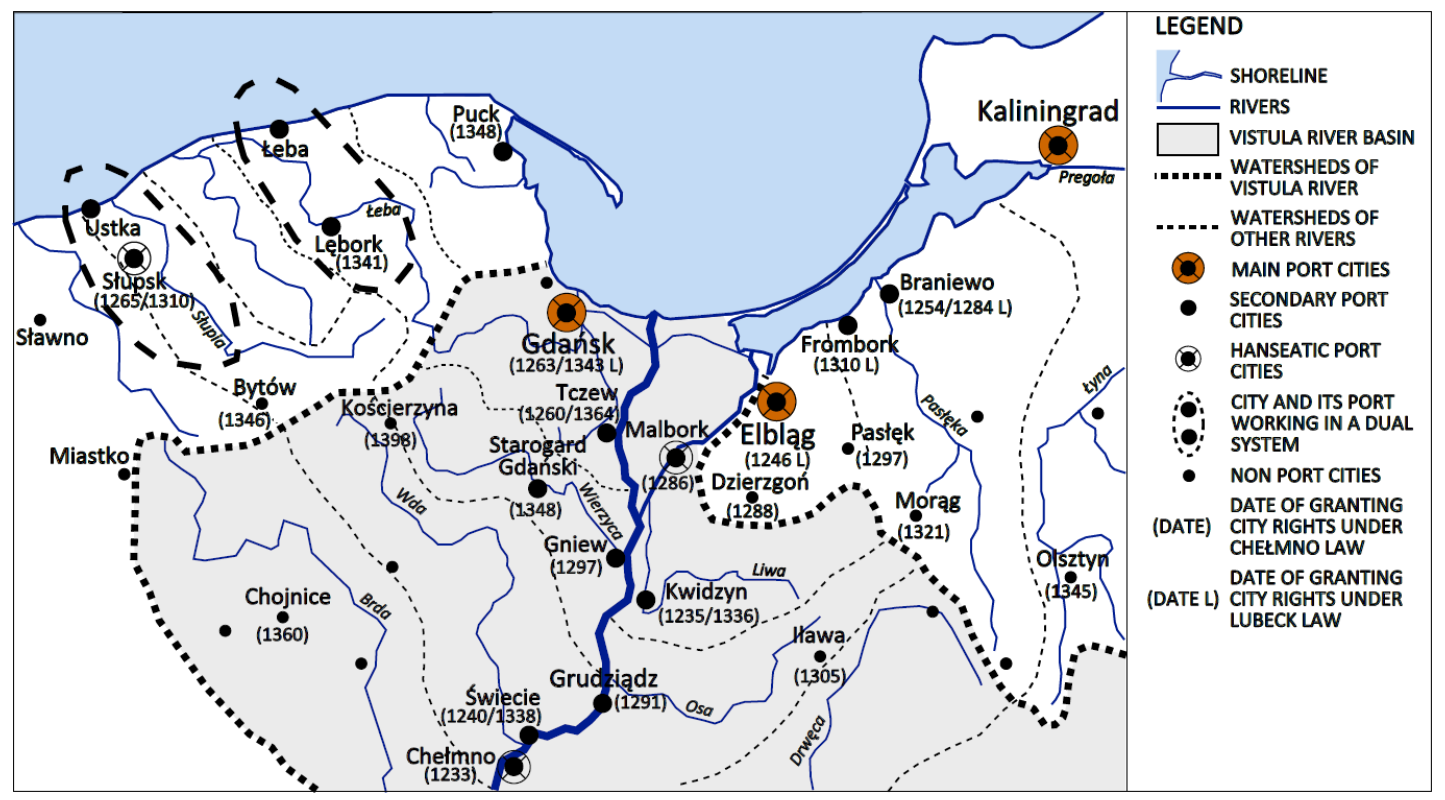

Figure 4. Gdańsk Bay port region geography in Hansa times (around the year 1400). The hinterland is defined by the accessibility of water transport. The lines of watersheds are shown approximately. 
collected loads from their entire river basin (e.g., Wda, Osa, Liwa, and Wierzyca). Usually, in the upper reaches of each river, there was at least one larger center organizing the flow of goods and people (e.g., Czersk, Iława, and Starogard Gdański).

Port cities located on the Vistula River conducted deep-sea trade, and some of them belonged to the Hanseatic League (Chełmno and Malbork). Similarly, the ports located at the mouths of rivers directly flowing into the sea (not belonging to the Vistula basin) pursued an independent maritime policy (the Hanseatic cities of Braniewo and Słupsk as well as Frombork and Lębork), additionally playing the role of feeder ports for Gdańsk or Elbląg. At this stage, the port region was quite homogenous, although the diversity of the size and importance of port cities and their hinterlands gave the canvas for further differentiation and the porosity of its structure.

At the end of the 14th century, the mainstream of the Vistula, which until then had led through Nogat to Elbląg, changed its direction towards the Gdańsk section due to hydrographic changes. This resulted in a gradual decline in the importance of the port in Elbląg (the depths available to ships in the port decreased significantly), but strengthened the position of the port in Gdańsk (Zbierski, 1964, p. 175). Around 1560, the inhabitants of Malbork and Elbląg made a ditch on the Vistula (Szopowski, 1959, p. 35), which again directed the waters towards Elbląg. However, with the decree of the king of Poland from 1612 (Cieślak et al., 1982, p. 501), the waters of the Vistula were redirected mostly to Gdańsk, weakening again the importance of the port in Elbląg. This single political decision shaped the further history of the region.

The decision that weakened the position of the Braniewo and Frombork ports was the building of the city of Pilau (Battijsk), which, thanks to its location at the entrance to the Vistula Lagoon, could control the movement of units within the entire Vistula Lagoon. The district of New Port in Gdańsk was built for similar reasons. Its location at the mouth of the Vistula River allowed for the control of all traffic on the river (including the old port in Gdańsk) while allowing the handling of larger and more modern ships (Cieślak \& Biernat, 1969, p. 275).

\subsection{At the Turn of the 19th and 20th Centuries}

In 1825, the provinces of Ostpreussen and Westpreussen were connected and Königsberg became the capital of the newly joined provinces. Gdańsk became a provincial garrison city and its economic development slowed down (Stankiewicz \& Szermer, 1959, p. 172), even though in the years 1854-1865 it was the main operational base of the Prussian navy. The situation changed with the industrial revolution and the introduction of railways to Gdańsk.

With the increasing drafts of ships, the introduction of steam engines, and the connection of the railway line to the ports of Gdańsk, Elbląg, and Königsberg in the 1860s (and then also to Słupsk and Lębork), the economic base of the Gdańsk Bay port region changed completely. The development of the railroad system meant the extension of the port region's hinterland to the area served by the rail network. This phenomenon completely rebuilt the hierarchy of city importance in the region, giving preference to those located at the railway hubs or at least having access to the railway network (Figure 5). The process contributed to the increasing porosity of the hinterland, which in some areas had become discontinuous.

At that time, the cities of Tczew, Malbork, Grudziądz, Olsztyn, Szczecinek, and Nowy Dwór Gdański developed

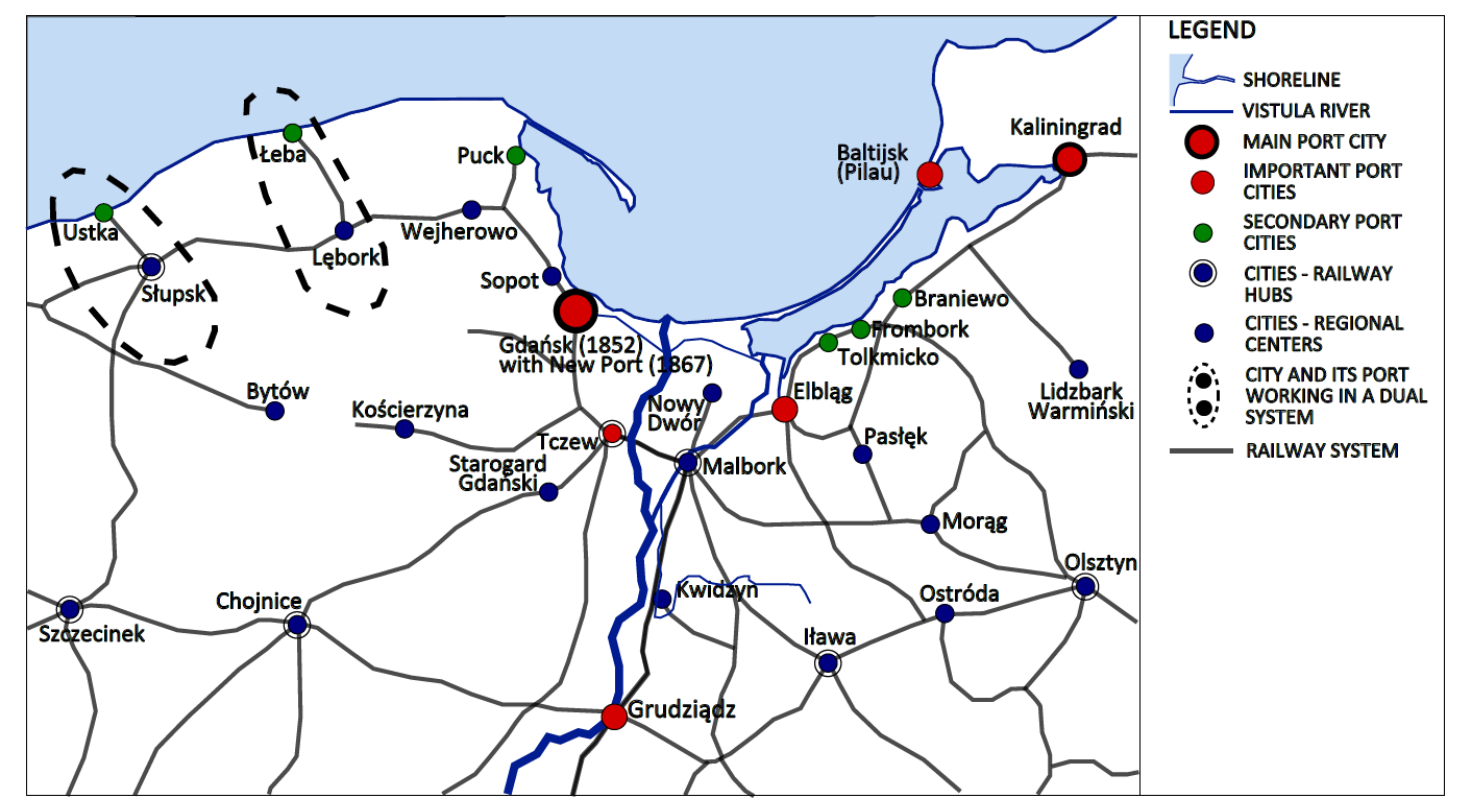

Figure 5. Gdańsk Bay port region geography at the end of the 19th century (around the year 1900). Source: Authors based on Lijewski and Koziarski (1995). 
significantly. The development of industry and bringing the rail network to the main ports resulted in the construction of a new deep-water port infrastructure outside the old areas of the port cities of Gdańsk, Elbląg, and Königsberg. The shipbuilding and machine industry also developed in these ports (Cieślak et al., 1972, pp. 240-256). At the same time, the position of small ports (Ustka, Łeba, Puck, Tolkmicko, Frombork, Braniewo), despite large investments carried out in their area, decreased in comparison to the dominant port cities. Inland ports with an economy based on smaller rivers ceased to be important as transshipment centers unless they developed based on rail transport. During this period, the health and spa functions also developed (based on new railway connections), which led to the development of such port cities as Svetlogorsk (connecting to the railway in 1906), Sopot (in 1870), Łeba, Ustka, as well as the districts of Gdańsk Brzeźno and Stogi (based on a tram connection).

\subsection{Interwar Period (1919-1938)}

As a result of the provisions of the Treaty of Versailles (1919), state borders were changed within the Gdańsk Bay port region and the area was divided among three states: Poland, the Free City of Gdańsk, and Germany (including East Prussia located east of Gdańsk). Thus, three cities became new centers for independent states: Gdynia for the northern part of Poland, Gdańsk for the Free City, and Königsberg for East Prussia.

The Free City of Gdańsk had a small direct hinterland (including a source of food supply in the form of Żuławy area) and the port of Gdańsk was largely cut off from the economic base by the state border. Poland's access to the sea, in turn, resulted in the construction of a port in
Gdynia (Sołtysik, 1993), as competition for Gdańsk, and a modern city connected with it (Figure 6). The port in Gdynia has been equipped with a railway line independent of Gdańsk, passing through Kościerzyna and Kartuzy, and activating these areas economically (Stankiewicz \& Szermer, 1959). Another Polish investment in the port region of the Gdańsk Bay was the construction of a modern fishing port in Władysławowo, which also serves as a small transshipment port. As a result, the already porous port region was subdivided into four politically independent systems, which due to complicated international relations did not create any economic unity. At the same time, each of those sub-regions became more coherent in terms of logistics and economic ties.

The ports of Lębork and Łeba, located in Germany, continued to operate in a double system, together with the much larger cities of Słupsk and Lębork. In the described period, the tourist and curative functions of centers such as Krynica Morska, Jurata, Jastarnia, and Jastrzębia Góra developed. Svetlogorsk, Sopot, Łeba, and Ustka also developed in terms of health resorts. The ports in Tolkmicko, Frombork, and Braniewo served as agricultural support centers.

\subsection{Period of the People's Republic of Poland (1945-1989)}

After the end of World War II, the Gdańsk Bay port region was divided into a Polish part with the centers in Gdańsk and Gdynia, and a Soviet Union part with its center in Kaliningrad (Figure 7). The port region of the Gdańsk Bay was seriously damaged as a result of hostilities during World War II. Until the 1960s, the port and shipyard infrastructure underwent reconstruction in this area.

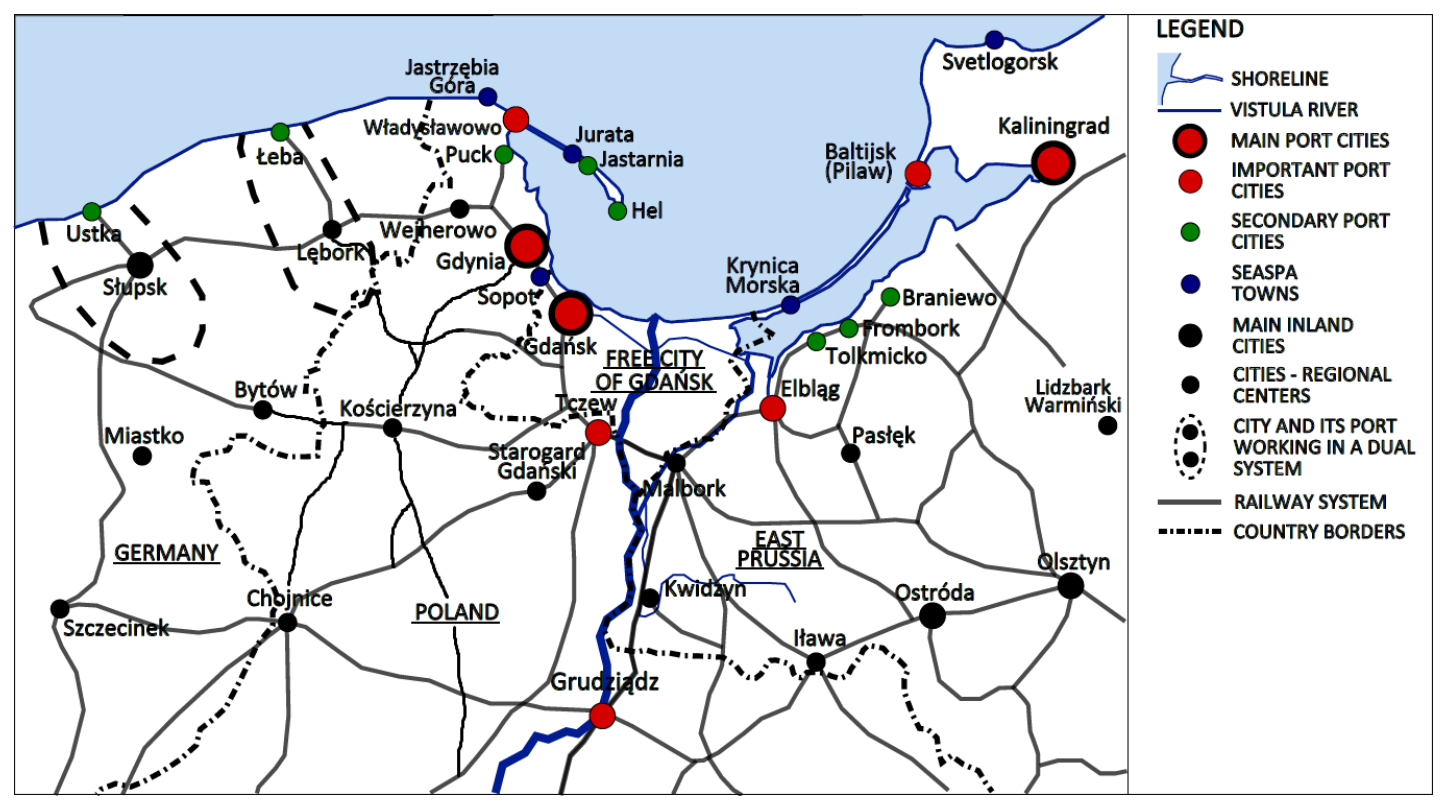

Figure 6. Gdańsk Bay port region geography during the interwar period. Source: Authors based on Lijewski and Koziarski (1995). 


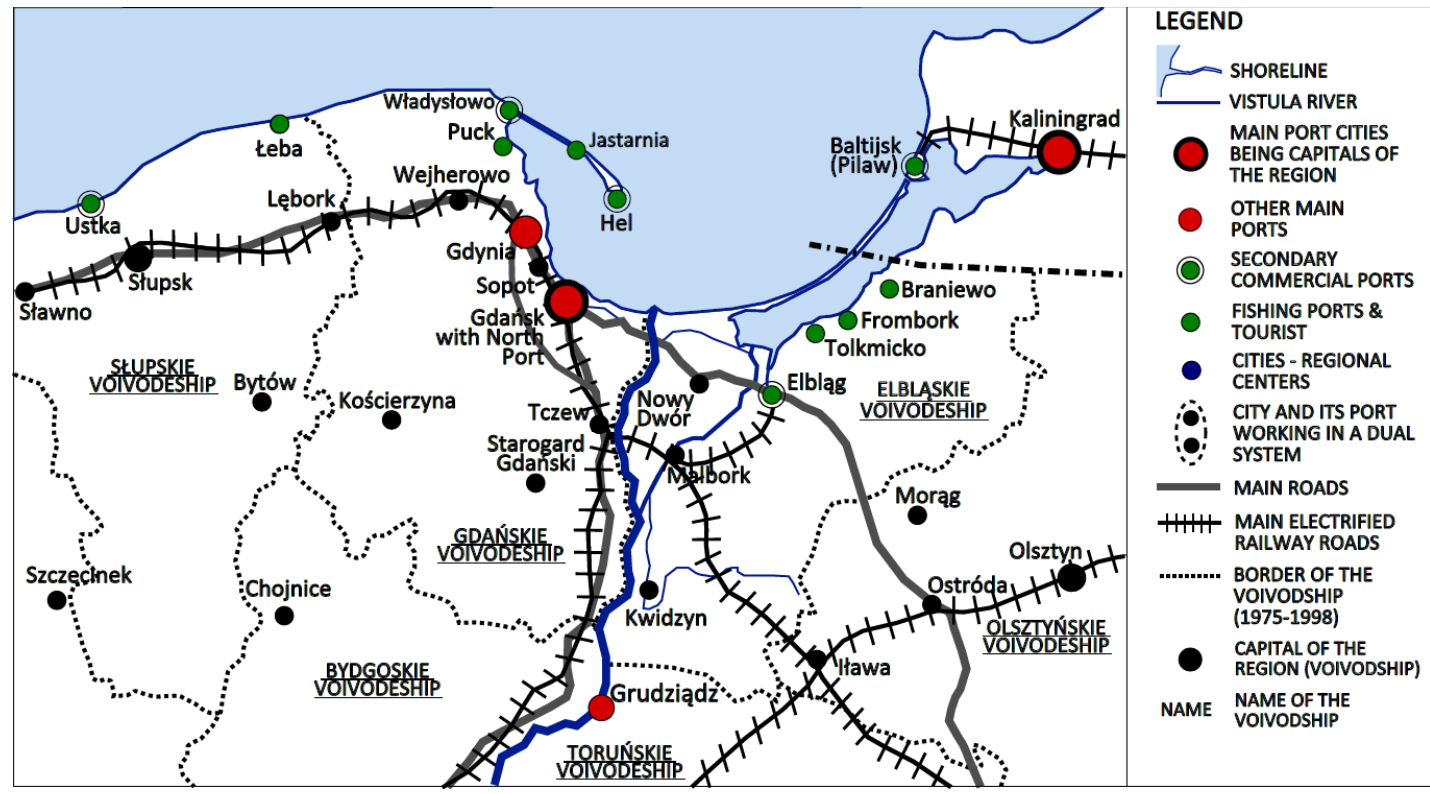

Figure 7. Gdańsk Bay port region geography during the period of 1945-1989.

During this period, tankers and bulk carriers with a draft of about $15 \mathrm{~m}$ and a carrying capacity of up to 150,000 DWT, called Baltimax, began to enter the Baltic Sea (Piskozub, 1986). However, the Baltic ports were not fully adapted to handle such large vessels. In the years 1970-1975, a modern, deep-water northern port was built in Gdańsk, which ensured Gdańsk's competitive advantage over other areas of the region (Piskozub, 1986, p. 190). Kaliningrad, as the capital of the region (oblasti), was still a very important port center. The Port of Gdynia was thoroughly modernized and, by political decision (centrally controlled economy), dedicated mainly to general cargo handling (from 1969 also containers). The significance of the port in Elbląg, which could not serve seagoing vessels due to depth deficits, decreased significantly. The remaining ports in the region (except Ustka and Władysławowo) gradually lost their reloading functions and became fishing ports with a tourist service.

The northern port in Gdańsk handled mainly Polish coal for export and liquid fuels for import and transit. Based on the liquid fuel terminal in Gdańsk, a refinery was built, connected by the 'Przyjaźni' pipeline with the transmission system of other socialist countries (Piskozub, 1986, p. 190). At the same time, the shipbuilding and industrial potential were significantly developed in Gdańsk. Bulk cargo handling, just like most general cargo, was mainly based on the railway system, in which electrified main railway lines became the most important (the remaining railway system did not change much). The electrification of the Wejherowo-Gdańsk section resulted in the linear development of the cities along the railway line and the formation of a three-center urban complex called the Tri-City (Gdańsk-Gdynia-Sopot). This situation led to the restoration of the porous port region. Its structure includes main transportations spines, as well as economically and logistically excluded parts.
A very important factor that influenced the settlement system of the port region of the Gdańsk Bay was the reform carried out in 1975, which introduced a twotier administrative division into provinces (voivodships) and communes (municipalities). Gdańsk, Słupsk, Elbląg, and Olsztyn became the capitals of voivodeships, thus strengthening their position as regional centers.

\subsection{Post-Socialist Period (from 1990)}

The development of the global container network has contributed to the strengthened position of the port in Gdynia and the development of its close logistics facilities. In 2006, a modern deep-water container and reloading terminal was built in Gdańsk, which resulted in part of the cargo stream being moved from Gdynia (with its greater depth limitations) to Gdańsk. Currently, however, both ports plan to build external ports dedicated to container handling (Krośnicka, 2019).

An extremely important factor in the development of the Gdańsk Bay port region was Poland's accession to the EU in 2005, which enabled the opening of new markets and expansion of the facilities in the ports of Gdańsk and Gdynia. The Kaliningrad port, cut off from its economic hinterland, has more difficult conditions for development in this context. However, still, some crossborder economic relations are taking place (Palmowski \& Fedorov, 2020).

The development of car transport and the expansion of road infrastructure (especially expressways and highways) made it possible to carry out cargo delivery in a 'door-to-door' relationship. This strengthened the share of car transport in port turnover and created the need of vast zones for logistics activities. These zones, with a specific large-volume landscape, extend mainly along the main road routes (Figure 8 ). This contributed to a 


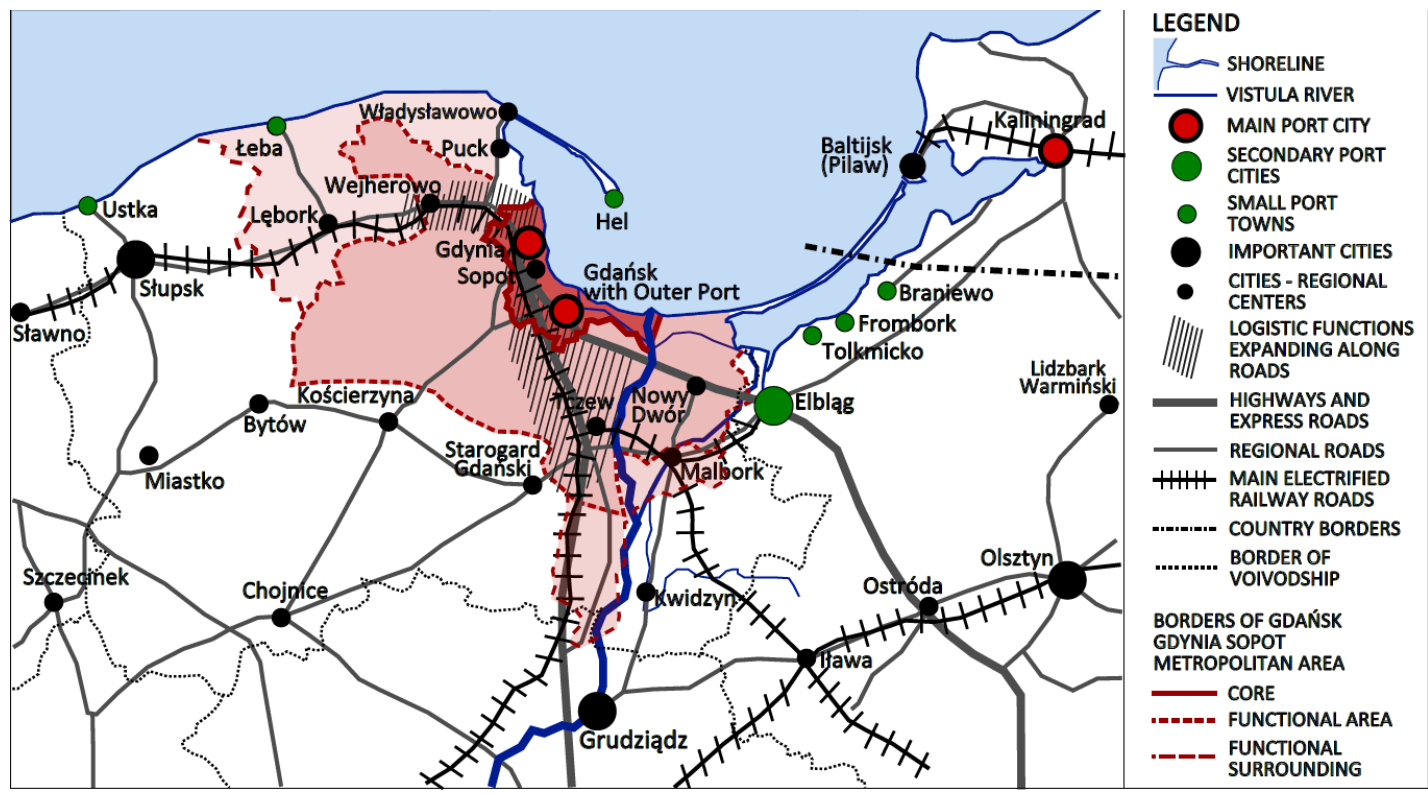

Figure 8. Contemporary Gdańsk Bay port region geography.

redefinition of the porous structure of the Gdańsk Bay port region and its dual character based on differences between deep-water cargo-handling infrastructure and leisure-oriented seaside towns.

Currently, apart from the port of Elbląg, for which investment has been made to improve the port's accessibility from the water (a ditch through the Vistula Spit), other ports are small centers of low demographic importance in the settlement structure of the region. Although they basically do not carry out any reloading activities, they are extremely important tourist centers supporting the economy of the region.

\section{Discussion}

The analyzed evolution of spatial changes in the Gdańsk Bay port region generally fits the theoretical models of the port-city relationship defined by Hoyle (1998) and Meyer (1991), as well as the model of the port system developed by Notteboom and Rodrigue (2005). In the case of Gdańsk Bay area, however, there is a periodic distortion in the standard course of the port region evolution caused by political factors, including, above all, the very frequent changes of territorial borders in the 1000-year history of this region (including borders of countries and voivodships). It can be assumed that if the entire area of the Gdańsk Bay had remained within one country, the concentration of cargo in one city and the centralization of the port system would have taken place under the model of Notteboom and Rodrigue (2005).

Considering such an alternative scenario for the development of the Gdańsk Bay port region elaborated according to the subsequent phases of the Notteboom and Rodrigue (2005) model, it could be supposed that Gdańsk would have ultimately become the central city of the region. In the first phase (dominance of inland trans- port), the port cities of Gdańsk and Elbląg would have had the greatest chance of fulfilling such a central function, due to their location in the estuary section of the Vistula, which made it possible to control the cargo flow of the entire Vistula river basin. Königsberg would have been slightly less important as a port city collecting loads from the Pregoła river basin-smaller in area than the Vistula basin. Further fate related to the construction of the railway system and bringing it to these three major port cities would probably have led to fairly even development in the importance of these three centers. In the interwar period, the port and the city of Gdynia would not have been created as competition for Gdańsk, under the conditions of the port region functioning within the same political and economic borders. In the post-war period (if a decision had been made to rebuild the port in Gdańsk at all), it can be assumed that due to the most favorable depth conditions of the port of Gdańsk (the depth of the port of Gdańsk reaches 15-16.5 m, the port of Kaliningrad is approximately $9-10 \mathrm{~m}$, the port of Elbląg approximately $4-5 \mathrm{~m}$ ) infrastructure investments, and with them the cargo mass, would have been concentrated in the port of Gdańsk. Thus, it can be presumed that given a situation of political continuity, the port city of Gdańsk would currently be the main center of the port region, within which port functions would be distributed among individual centers of minor importance. In the absence of a border with Russia, the port city of Kaliningrad would probably not have been as important as it is today, but it would have been included in the port region complex as a feeder port. In turn, the cities of Elbląg or Tolkmicko and Frombork, as located in the interior of the port region, would have been more important and not on the edge of the system as it is today.

This alternative development scenario for the Gdańsk Bay port region was presented here as a kind 
of discussion on the port region's evolution process. It shows how both the changes made to the national borders and the historical geopolitical situation in which the region is embedded have profoundly influenced the current economic situation and the hierarchy of urban centers. From the point of view of this alternative scenario, we would observe a very different level of porosity within the port region than we see today.

\section{Conclusions}

Currently, there are three strong port centers in the Gdańsk Bay port region: Gdańsk, Gdynia, and Kaliningrad. The first two, due to their geographic proximity, rely on the common potential of transport and logistics infrastructure and human capital. At present, mainly as a result of the containerization process, the hinterland of the ports of Gdańsk and Gdynia is dynamically deepening. In a way, this serves as an analogy to the situation observed in the Middle Ages, when there were port centers located along the Vistula River to support the transfer of cargo from slightly smaller areas (equivalents of today's intermodal terminals or dry ports located in a distant hinterland). However, the close hinterland of the ports of Gdynia and Gdańsk has shrunk significantly. Most of the nearby areas and small ports of the Gdańsk Bay region do not currently cooperate with the ports of Gdańsk and Gdynia, but focus on functions related to the development of tourism or fishing as they gradually undergo the process of 'de-maritimization' (Merk, 2018). The ports of Władysławowo and Hel may have a chance to assume niche functions related to the maritime economy (servicing wind farms). However, it is currently difficult to determine to what extent these opportunities will be used.

In addition to environmental (the hydrological network of the hinterland of the port region) and technological factors (water, rail, and road transport infrastructure), the range and structure of the functional areas of port city regions are the result of political and economic decisions, such as changes in borders or economic and political investments. Examples given include: the redirection of waters from Nogat to the Gdańsk Vistula by decree of the King of Poland in 1612 (Cieślak et al., 1982 , p. 501); the construction of the new port in Gdańsk to control cargo heading to and from the old port of Gdańsk (Cieślak \& Biernat, 1969, p. 275); the construction of the port in Gdynia in the 1930s to compete with the port of Gdańsk (Sołtysik, 1993); and currently plans to build deep-water ports in Gdańsk and Gdynia or the ditch across the Vistula Spit. As a result of such decisions, the geography of the port region is a dynamically changing mosaic of cities with different opportunities, hierarchies, and stages of development. Thus, the porosity of a port region evolves along with changing borders and can be strongly influenced by politics and developments in infrastructure, among other factors.

\section{Conflict of Interests}

The authors declare no conflict of interests.

\section{References}

Bird, J. (1963). The major seaports of the United Kingdom. Hutchinson.

Brooks, M., \& Cullinane, K. (2007). Devolution, port governance and port performance. Elsevier.

Cieślak, E., \& Biernat, C. (1969). Dzieje Gdańska [The history of Gdańsk]. Wydawnictwo Morskie Gdańsk.

Cieślak, E., Binerowski, Z., Czajka, T., BojanowskaDzieduszycka, I., Gierszewski, S., \& Gulda, M. (1972). Historia budownictwa okrętowego na Wybrzeżu Gdańskim [The history of shipbuilding on the Gdańsk coast]. Wydawnictwo Morskie Gdańsk.

Cieślak, E., Stankiewicz, J., Samsonowicz, H., Bogucka, M., Nowak, Z., \& Czapliński, W. (1982). Historia Gdańska 1454-1655. Tom II [The history of Gdańsk 1454-1655. Volume II]. Wydawnictwo Morskie Gdańsk.

Daamen, T. A., \& Vries, I. (2013). Governing the European port-city interface: Institutional impacts on spatial projects between city and port. Journal of Transport Geography, 27, 4-13. https://doi.org/10.1016/ J.JTRANGEO.2012.03.013

Dollinger, P. (1975). Dzieje Hanzy [The German Hansa]. Wydawnictwo Morskie Gdańsk.

Ducruet, C. (2009). Port regions and globalization. In T. E. Notteboom, C. Ducruet, \& P. W. de Langen (Eds.), Ports in proximity: Competition and coordination among adjacent seaports (pp. 41-53). Ashgate.

Ducruet, C. S., Itoh, H., \& Joly, O. (2015). Ports and the local embedding of commodity flows. Regional Science, 94(3), 607-627.

European Sea Ports Organisation. (2020). ESPO's roadmap to implement the European Green Deal objectives in ports. https://www.espo.be/media/ ESPO\%20Green\%20Deal\%20position\%20paper\% 20Green\%20Deal-FINAL_3.pdf

Faludi, A. (2009). The Megalopolis, the Blue Banana, and global economic integration zones in European Planning thought. In C. L. Ross (Ed.), Megaregions: Planning for Global Competitiveness (pp. 18-34). Island Press.

Ferrari, C., Merk, O., Bottasso, A., Conti, M., \& Tei, A. (2012). Ports and regional development: A European perspective (OECD Regional Development Working Papers, 2017/07). OECD Publishing. https://doi.org/ $10.1787 / 20737009$

Hall, P. (1993). Waterfronts: A new urban frontier. In R. Bruttomesso (Ed.), Waterfronts: A new frontier for cities on water (pp. 12-19). Centro Internazionale Citta D’Acqua.

Haynes, K. E. (2010). Governance of Infrastructure. In S. Buijs, W. Tan, and D. Tunas (Eds.), Megacities: Exploring a sustainable future (pp. 254-272). OIO Publishers. 
Hein, C. (2014). Port cities and urban wealth: Between global networks and local transformations. International Journal of Global Environmental Issues, 13(2/3/4). https://doi.org/10.1504/IJGENVI.2014. 064510

Hein, C., \& van Mil, Y. (2019). Towards a comparative spatial analysis for port city regions based on historical geospatial mapping. PORTUSplus, 8(Special Issue), 1-18.

Hoyle, B. S. (1993). Some Canadian dimensions of waterfront redevelopment. In R. Bruttomesso (Ed.), Waterfronts: A new frontier for cities on water (pp. 333-338). Centro Internazionale Citta D’Acqua.

Hoyle, B. S. (1996). Ports, cities and coastal zones: Competition and change in a multimodal environment. In B. S. Hoyle (Ed.), Cityports, coastal zones and regional change (pp. 1-6). John Wiley \& Sons.

Hoyle, B. S. (1998). Cities and ports: Development dynamics at the port-city interface. In R. Bruttomesso (Ed.), Land-water intermodal terminals (pp. 5-11). Marsilio.

Hoyle, B. S., \& Hilling, D. (1984). Seaport system and spatial change: Technology, industry and development strategies. John Wiley \& Sons.

Hoyle, B. S., \& Pinder, D. A. (Eds.). (1981). City port industrialization and regional development. Pergamon Press.

Jałowiecki, B. (1999). Współczesne przekształcenia struktury osadniczej i przestrzeni miejskiej [Contemporary transformations of the settlement structure and urban space]. In J. Kołodziejski \& T. Parteka (Eds.), Cywilizacja informacyjna a przekształcenia przestrzeni. Zmiany strukturalne metropolii polskich [Information civilization and transformations of space. Structural changes in Polish metropolises] [Special Issue]. Biuletyn KPZK PAN, 186. Polska Akademia Nauk.

Krośnicka, K. A. (2018). Spatial evolution of the European container ports' system in perspective of the location theory, GlobMar Conference Proceedings, 58, 01016. https://doi.org/10.1051/shsconf/20185801016

Krośnicka, K. A. (2019). Container port expansion towards the sea in the context of maritime spatial planning. Europa XXI, 36, 107-115. https://doi.org/ 10.7163/Eu21.2019.36.9

Lijewski, T., \& Koziarski, S. (1995). Rozwój sieci kolejowej $w$ Polsce [Development of the railway network in Poland]. Kolejowa Oficyna Wydawnicza.

Lorens, P. (2014). Urban waterfront regeneration: Origins of the issue. In S. G. Dundar, N. Karatas, H. E. Erdin, \& P. Lorens (Eds.), New faces of harbor cities. Cambridge Scholars Publishing.

Merk, O. (2018). Container ship size and port relocation. OECD and International Transport Forum. https://www.itf-oecd.org/container-ship-size-portrelocation

Meyer, H. (1991). Port of Rotterdam. In S. K. Al Naib (Ed.), European docklands: Past, present and future. North
East London Polytechnic.

Meyer, H. (1999). City and port. International Books.

Munim, Z. H., \& Schramm, H. J. (2018). The impacts of port infrastructure and logistics performance on economic growth: The mediating role of seaborne trade. Journal of Shipping and Trade, 3(1), 1-19. https:// doi.org/10.1186/s41072-018-0027-0

Musso, E., Benacchio, M., \& Ferrari, C. (2000). Ports and employment in port cities. International Journal of Maritime Economics, 2(4), 283-311. https://doi.org/ 10.1057/ijme.2000.23

Ng, A. K. Y., Ducruet, C., Jacobs, W., Monios, J., Notteboom, T., Rodrigue, J.-P., Slack, B., Tam, K., \& Wilmsmeier, G. (2014). Port geography at the crossroads with human geography: Between flows and spaces. Journal of Transport Geography, 41, 84-96. https://doi.org/10.1016/j.jtrangeo.2014.08.012

North, M. (2018). Historia Battyku [The history of the Baltic Sea]. Neriton.

Notteboom, T., Ducruet, C., \& de Langen, P. (Eds.). (2009). Ports in proximity: Competition and coordination among adjacent seaports. Ashgate.

Notteboom, T. E., \& Rodrigue, J. P. (2005). Port regionalization: Toward a new phase in port development. Maritime Policy and Management, 32(3), 297-313.

Palmowski, T., \& Fedorov, G. M. (2020). The potential for the development of Russian-Polish crossborder region. Geography, Environment, Sustainability, 13(1), 21-28. https://doi.org/10.24057/20719388-2019-70

Park, J. S., \& Seo, Y.-J. (2016). The impact of seaports on the regional economies in South Korea: Panel evidence from the augmented Solow model. Transportation Research Part E: Logistics and Transportation Review, 85, 107-119.

Piskozub, A. (1986). Polska morska. Czyn XX wieku [Maritime Poland. The act of the 20th century]. Wydawnictwo Morskie Gdańsk.

Ressano Garcia, P. (2008). The role of the port authority and the municipality in port transformation: Barcelona, San Francisco, and Lisbon. Planning Perspectives, 23(1), 49-79. https://doi.org/10.1080/ 02665430701738032

Sassen, S. (2010). Urban economies and fading distances. In S. Buijs, W. Tan, \& D. Tunas (Eds.), Megacities: Exploring a sustainable future (pp. 46-55). OIO Publishers.

Schubert, D. (2018). Ports and urban waterfronts. In C. Hein (Ed.), The Routledge handbook of planning history (pp. 338-349). Routledge.

Sołtysik, M. (1993). Gdynia-miasto dwudziestolecia międzywojennego. Urbanistyka i architektura [Gdynia-The city of the interwar period. Town planning and architecture]. Polskie Wydawnictwo Naukowe.

Stankiewicz, J., \& Szermer, W. (1959). Gdańsk. Rozwój urbanistyczny $i$ architektoniczny oraz powstanie zespołu Gdańsk-Sopot-Gdynia [Gdańsk. Urban and 
architectural development and the rise of the Gdańsk-Sopot-Gdynia complex]. Arkady.

Stavroulakis, P. J., \& Papadimitriou, S. (2016). The strategic factors shaping competitiveness for maritime clusters. Research in Transportation Business \& Management, 19, 34-41. https://doi.org/10.1016/j.rtbm. 2016.03.004

Szopowski, Z. (1959). Porty morskie. Projektowanie i eksploatacja [Sea ports. Design and operation]. Polskie Wydawnictwo Naukowe. van den Berg, L., Braun, E., \& van der Meer, J. (1997). Metropolitan organizing capacity. Ashgate.

Wiegmans, B. W., \& Louw, E. (2010). Changing portcity relations at Amsterdam: A new phase at the interface? Journal of Transport Geography, 19(4), 575-583.

Zbierski, A. (1964). Port gdański na tle miasta w X-XIII $w$. [The port of Gdańsk against the background of the city in the 10th-13th centuries]. Gdańskie Towarzystwo Naukowe.

\section{About the Authors}
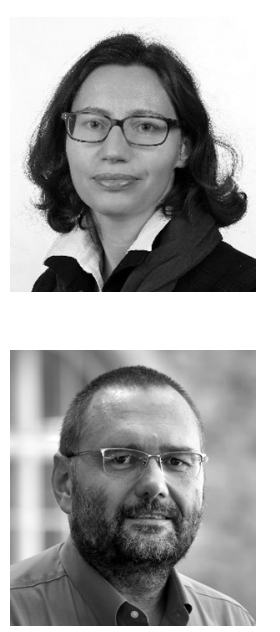

Karolina A. Krośnicka, Ph.D., D.Sc., educated as an architect and urban planner, is currently Associate Professor in the Department of Urban Design and Regional Planning, Faculty of Architecture, Gdańsk University of Technology (Poland). Her current research interests concentrate on the port-city spatial relations, planning of ports and post-port areas, Integrated Coastal Zone Management, and the theory of urban dynamics.

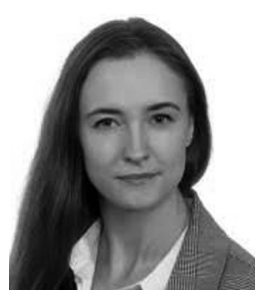

Piotr Lorens, Ph.D., D.Sc., is an Urban Planner, Gdańsk City Architect (since 2021), Lecturer in Urban Design and Development, and Head of the Department of Urban Design and Regional Planning at the Faculty of Architecture, Gdańsk University of Technology (since 2007). His research interests include urban planning and regeneration processes, with a special focus on waterfront areas and public spaces.

Eliza Michałowska holds a Master's in Spatial Planning, received in 2019 at the Faculty of Architecture, Gdańsk University of Technology (Poland). She is currently a Junior Acquisition Manager in Vastint Poland. Her research interests concentrate on the directions of development of intelligent port cities and port-city relations. 